\title{
EFFECT OF NITROGEN AND BIOFERTILIZATION, SEAWEED EXTRACT AND THIAMINE ON GROWTH, YIELD AND ESSENTIAL OIL OF PARSLEY PLANT
}

\author{
M.K.A. Aly, E.T. Ahmed, M.A.H. Mahmoud, El-Zahraa N. Youssef \\ Hort. Dept., Fac. Agric., Minia Univ., Minia, Egypt
}

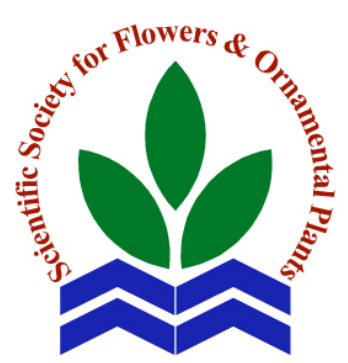

Scientific J. Flowers \& Ornamental Plants, 8(2):235-249 (2021).

Received:

31/3/2021

Accepted:

$3 / 5 / 2021$

Corresponding author: M.A.H. Mahmoud mmahmohamed@gmail.com

\begin{abstract}
A field experiment was carried out to study the effect of reducing the recommended dose of mineral $\mathrm{N}$ fertilizer on parsley (Petroselinum sativum, Hoffm.) plants. To achieve this aim, some biostimulants commercial product (Minia azotein) which contain $\mathrm{N}$ fixing bacteria, seaweeds extract at 100 and $200 \mathrm{ppm}$ and thiamine (Vit. B1) at 100 and $200 \mathrm{ppm}$, separately or in combinations were used. Results revealed that mineral $\mathrm{N}$ at 50 to $75 \%+$ Minia azotein significantly stimulated the vegetative growth traits, yield components, essential oil content, photosynthetic pigments and $\mathrm{N} \%$ relatively to control plants (recommended dose of mineral $\mathrm{N}$ ). Using mineral $\mathrm{N}$ fertilizer at 25\% and Minia azotein significantly reduced the above-mentioned characters compared to check treatment. All treatments of seaweeds extract and/or thiamine (Vit. B1) significantly augmented the vegetative growth parameters, yield components, essential oil photosynthetic pigments and $\mathrm{N} \%$ compared with control plants. The most effective treatment was seaweeds extract and Vit. B1 both at 200 ppm. The best results with regard to the herb dry and, fruit weight and essential oil productivity were obtained as a result of using $\mathrm{N}$ fertilizer at $50 \%$ plus Minia azotein in combinations with seaweeds extract + Vit. B1 each at $200 \mathrm{ppm}$.
\end{abstract}

Key words: Petroselinum sativum, bio-stimulants, N fixing bacteria, seaweeds extract, thiamine.

\section{INTRODUCTION}

Parsley (Petroselinum sativum, Hoffm.) plants belong to the family Apiace (Umbelliferae) is an aromatic bright green, annual or biennial herb (Simon, 1999). Leafy parsley is recognized as a spice native to the Mediterranean countries. It is widely used as fresh, dry or frozen herb to enhance the flavor of different types of foods. Parsley seeds have been used as antiseptic treatment, inflammation, kidney stones and also as carminative (Moazedi et al., 2007 and Behtash et al., 2008). Parsley plants have been used as a medicinal plant for diverse medicinal purposes in traditional and folklore medicine of many countries (Blumenthal et al., 2000). Parsley seeds produce high amount of essential oil (EO) with monoterpenes as a main constituents. This EO could be used in the food industry and as a perfume fragrance (Diaz-Maroto et al., 2002).

Nitrogen is an essential element for all living organisms as it is involved in biosynthesis of many molecules such as proteins, enzymes and nucleic acids. However, a small ratio of it is present in the soil, yet a tiny portion of soil-N is available to the plants (Mengel et al., 2001). A plant bio-stimulant is a substance or microorganism such as seaweed and thiamine (vitamin B1), that could encourage natural developments of plants and promoting their nutrient use efficiency (Torre et al., 2013). Biofertilizers are one of these bio-stimulants which afford an 
economically cheap and ecologically safe fertilizer moreover, they are vital for sustainable agriculture by reducing the doses of chemical fertilizers (Chatterjee et al., 2017). Minia azotein (MA) (N-fixing biofertilizer) as a bio-stimulant has been applied to reduce mineral $\mathrm{N}$ fertilizer of different herbs (Abdallah et al., 2012) and (Shehata, 2019) on parsley; (Abdou et al., 2020) on fennel and (El-Sayed et al., 2020) on dill.

Seaweeds (SE) are significant marine renewable materials that used as a replacement of chemical fertilizer due to their content of many macronutrients, micronutrients and growth regulators (Khan et al., 2009). Seaweeds extract has been used to improve the growth and productivity of many medicinal plants (Ramya et al., 2011 on guar; Aqeel et al., 2014 on Nigella sativa, Hassan, 2015 on Anethum graveolens; Mahmoud, 2016 on Calendula officinalis and Veeranan et al., 2018 on Ocimum sanctum).

Vitamin B1 (thiamine) acts as cofactor and activator for many plant metabolic activities especially enzymes which involve in the synthesis of pentose phosphate pathway, amino acids, tricarboxylic acid cycle (Colinas et al., 2015 and Subki et al., 2018). Vit. B1 has been used as a biostimulants by many investigators on different medicinal crops (Hendawy and Ezz El-Din, 2010 on fennel; Botros, 2013 on caraway; Abdou et al., 2019 on cumin and Abdelkader et al., 2018 on black cumin).

Therefore, this study was conducted to assess the effects of replacing some mineral $\mathrm{N}$ fertilizer requirements by MA, SE and Vit.
B1 on the vegetative growth, fruit yield and EO and productivity of parsley plant.

\section{MATERIALS AND METHODS}

This investigation was carried out during the two successive seasons; 2016/2017 and $2017 / 2018$ at the nursery and laboratory of ornamental plants, Fac. of Agric., Minia Univ., Egypt. Seeds of parsley were obtained from Nursery of Floriculture, Fac. of Agric., Minia Univ. and sown on November $6^{\text {th }}$ in clay loamy soil. The physical and chemical analysis of the experimental soil is listed in Table (a).

A complete randomized block design following the split plot arrangement was executed. The main plots included 4 treatments of mineral $\mathrm{N}$ which were $\mathrm{N}$ as a unique source or in combination with the biofertilizer Minia azotein (MA) whereas, the sub plots contained 7 treatments of SE and/or Vit. B1. Minia azotein which is a commercial biofertilizer contains free living $\mathrm{N}$-fixing bacteria was obtained from Center of Biofertilizers, Dept. of Genetics, Fac. of Agric. Minia Univ. The components of seaweed extract which obtained from Lab. Chem, Cairo, Egypt is shown in Table (b).

The main plot was $3 \times 4.8 \mathrm{~m}$ with $60 \mathrm{~cm}$ distance between the rows and $30 \mathrm{~cm}$ between the hills within the row. So, each plot contained 7 rows and 70 hills (10 hills/row). Plants were thinned twice, the $1^{\text {st }}$ after 3 weeks from plating date and the $2^{\text {nd }}$ after 2 weeks from the $1^{\text {st }}$ one, finally each hill contained 2 plants. Overall there were 38 thousand plants/fed.

The main plots (A) treatments were control (recommended dose $(100 \%)$ of

Table a. Physical and chemical analysis of the experimental soil.

\begin{tabular}{|c|c|c|c|}
\hline Soil characters & Value & Soil characters & Value \\
\hline Soil type & Clayey loam & Avail. P (\%) & 15.40 \\
\hline Sand $(\%)$ & 28.59 & Exch. K (mg/100g) & 2.45 \\
\hline Silt (\%) & 30.29 & Exch. Ca (mg/100g) & 31.43 \\
\hline Clay & 41.12 & Exch. $\mathrm{Na}(\mathrm{mg} / 100 \mathrm{~g})$ & 2.46 \\
\hline Organic Matter (\%) & 1.65 & $\mathrm{Fe}$ & 8.39 \\
\hline $\mathrm{CaCO}_{3}(\%)$ & 2.10 & DTPA & 2.04 \\
\hline $\mathrm{pH}(1: 2.5)$ & 7.79 & Ext. (ppm) & 2.81 \\
\hline $\mathrm{EC}(\mathrm{mmhos} / \mathrm{cm})$ & 1.06 & $\mathrm{Mn}$ & 8.19 \\
\hline Total N (\%) & 0.08 & & \\
\hline
\end{tabular}


Table b. The chemical properties of the seaweeds extract.

\begin{tabular}{llll}
\hline Characters & Values & Character & Values \\
\hline Moisture (\%) & 6.0 & $\mathrm{~S}(\%)$ & $3-9$ \\
Organic matter (\%) & $45-65$ & $\mathrm{Ca}(\%)$ & $0.2-1.5$ \\
Inorganic matter (\%) & $45-65$ & $\mathrm{~B} \mathrm{ppm}$ & $20-100$ \\
Protein $(\%)$ & $6-8$ & $\mathrm{Mo} \mathrm{ppm}$ & $1-5$ \\
Carbohydrate (\%) & $35-50$ & Fe ppm & $50-200$ \\
Alginic acid (\%) & $10-20$ & $\mathrm{Cu} \mathrm{ppm}$ & $1.0-6.0$ \\
Mannitol & $4-7$ & Mn ppm & $5-12$ \\
Total N (\%) & $1.0-1.5$ & Zn ppm & $10-100$ \\
$\mathrm{~K}(\%)$ & $1.0-1.2$ & Cytokines $(\%)$ & 0.02 \\
$\mathrm{Mg}(\%)$ & $0.5-0.9$ & IAA $(\%)$ & 0.03 \\
$\mathrm{P}(\%)$ & ABA $(\%)$ & 0.01 \\
\hline
\end{tabular}

mineral $\mathrm{N}$ fertilizer as a unique source of $\mathrm{N}$ ) and $\mathrm{N}$ fertilizer at 25,50 and $75 \%$ of the recommended dose plus MA. The amounts of mineral $\mathrm{N}$ fertilizer for $25,50,75$ and $100 \%$ were $75,150,225$ and $300 \mathrm{~kg} / \mathrm{fed}$, respectively of ammonium sulphate $(20.6 \%$ $\mathrm{N})$. The $\mathrm{N}$ fertilizer was divided into two batches, added with 3 weeks interval, starting on $20^{\text {th }}$ December. A volume of 50 $\mathrm{ml} / \mathrm{hill}$ of the suspension culture of MA contains $1 \times 10^{7}$ cell was added twice, to the soil beside the plant at the same times of $\mathrm{N}$ fertilization. While, the sub plots (B) treatments were untreated plants (tap water), $\mathrm{SE}$ at 100 or $200 \mathrm{ppm}$, vit B1 at 100 or 200 ppm and SE + Vit. B1 each one at 100 or $200 \mathrm{ppm}$. Parsley plants were foliar sprayed thrice with 3 weeks interval till run off starting on $19^{\text {th }}$ December. In addition to those plants were sprayed after the $1^{\text {st }}, 2^{\text {nd }}$ and $3^{\text {rd }}$ cuts of the herb at one month intervals, starting on $15^{\text {th }}$ Feb. Therefore, the experiment involved 28 treatments each consisted of one row and replicated thrice.

All parsley plants received phosphorus at $200 \mathrm{~kg} / \mathrm{fed}$ of calcium superphosphate $\left(15.5 \% \mathrm{P}_{2} \mathrm{O}_{5}\right)$ and potassium fertilizers 50 $\mathrm{kg} /$ fed of potassium sulphate $\left(48 \% \mathrm{~K}_{2} \mathrm{O}\right)$. Organic farm yard manure at $20 \mathrm{~m}^{3} / \mathrm{fed}$ and $\mathrm{P}$ fertilizer were added during preparing of the soil for cultivation, while $\mathrm{K}$ fertilizer was added on $20^{\text {th }}$ December in both growing seasons. All other agriculture practices were carried out as usual in both seasons.

At harvesting time, half number of the plants was harvested to obtain the EO of herb (the herb was collected four times at one month intervals starting $5^{\text {th }}$ February however, the other plants were harvested once at end of the season (end of June) to obtain the essential oil (EO) from mature fruits. EO $\%$ of herb and fruits were determined according to British Pharmacopoeia (1963). Samples of fresh leaves were taken after 3 weeks from the last treatment to estimate the contents of the photosynthetic pigments (chlorophyll a, b, and carotenoids, $\mathrm{mg} / \mathrm{g}$ f.w.) according to Fadl and Sri El-Deen (1978). At the end of growing season the percentage of $\mathrm{N}$ in the dry leaves was determined according to Wilde et al. (1985). The obtained data were tabulated and subjected to statistical analysis according to Mead et al. (1993) using MSTAT-C (1986).

\section{RESULTS}

\section{Herb fresh and dry weights:}

Data presented in Table (1) show that factor A treatments except $\mathrm{N}$ at $25 \%+\mathrm{MA}$ caused a significant increase in herb fresh and dry weights/fed as compared to the control treatment in the two seasons. The heaviest fresh and dry weights of herb/fed were obtained due to $\mathrm{N}$ at $75 \%+\mathrm{MA}$ treatment followed by $\mathrm{N}$ at $50 \%+\mathrm{MA}$ (with no significant difference between them, in both seasons). The increments in herb dry weight/fed as a result of the previous treatments were 21.64 and $16.86 \%$ in the $1^{\text {st }}$ season and 23.01 and $15.34 \%$ in the $2^{\text {nd }}$ one, respectively over the control plants. Regarding the effect of factor B treatments, it was obvious that all tested treatment significantly augmented the fresh and dry 
M.K.A. Aly et al.




weights of parsley herb/fed compared with the check treatment (Table, 1). The best treatment which produced the heaviest fresh and dry weights was the dual treatment of seaweeds extract + Vit. B1 (each 200 ppm). This treatment increased the herb dry weight/fed. by 99.86 and $89.48 \%$ over that of the control plants in the two seasons, respectively.

The interaction between factor A and B was significant in the two growing seasons as shown in Table (1). Overall, the most effective treatments which produced the heaviest herb fresh and dry weights/fed in both seasons was $\mathrm{N}$ fertilizer at $75 \%$ or $50 \%$ $+\mathrm{MA}$ in combination with seaweeds extract+ Vit. B1 each at 200 ppm.

\section{Fruit yield:}

Parsley fruit yield was augmented due to fertilization treatments (except $\mathrm{N}$ fertilizer at $25 \%+\mathrm{MA})$ in comparison with control plants in both seasons. The augmentation of the yield was only significant for $\mathrm{N}$ fertilizer at $75 \%+\mathrm{MA}$, which augmented fruit yield/fed by $9.91 \%$ in $1^{\text {st }}$ season and $10.21 \%$ in the $2^{\text {nd }}$ one over the control plants (Table, 2). A significant increment of fruit yield was detected due to all treatments of factor B comparing with tap water treatment in both seasons as shown in Table (2). The highest value of fruits yield was obtained due to SE + Vit. B1 each at $200 \mathrm{ppm}$. This treatment enhanced fruit yield/fed by 77.79 and $75.75 \%$ over the tap water treated plants in the both seasons, respectively.

The interaction between the two investigated factors was significant in the two growing seasons (Table, 2). The best results of fruit yield were obtained from the treatment of $\mathrm{N}$ fertilizer at $50 \%+\mathrm{MA}$ in combination with SE + Vit. B1 each at 100 ppm in the $1^{\text {st }}$ season and in combination with SE +Vit. B1 both at $200 \mathrm{ppm}$ in the $2^{\text {nd }}$ one.

\section{Essential \% and yield/fed of parsley herb:}

Data recorded in Table (3) revealed that EO $\%$ and yield/fed of parsley herb were significantly increased, in most cases due to $\mathrm{N}$ fertilizer + MA treatments (except $\mathrm{N}$ at $25 \%+$ MA) compared with control treatment in both seasons. The highest percentage and yield/fed were achieved due to supplying plants with $\mathrm{N}$ at $75 \%+$ MA followed by $\mathrm{N}$ at $50 \%+$ MA (with no significant differences between themselves) in the two seasons. These treatments augmented the EO yield by 25.65 and $19.65 \%$ in the $1^{\text {st }}$ season and by 26.42 and $16.93 \%$ in the $2^{\text {nd }}$ one, respectively over those of control plants.

The obtained results (Table, 3 ) suggested that spraying parsley plants with SE and/or Vit. B1 at all tested concentrations resulted in a significant increment of EO \% and oil yield/fed as compared to tap water treatment in the two season. The highest values in this concern were obtained from spraying the plants with SE + Vit. B1 each one at 200 $\mathrm{ppm}$. The increment percentages of the EO yield/fed were 120.14 and $118.26 \%$ over that of control plants in the two seasons, respectively.

There was a significant interaction between the two investigated factors on EO $\%$ and oil yield/fed of parsley herb for both seasons. The highest values were obtained with the treatment of $\mathrm{N}$ fertilizer at $75 \%$ or $50 \%+\mathrm{MA}$ in combination with seaweeds extract + Vit. B1 each at 200 or 100 ppm for the two growing seasons, respectively.

\section{Essential \% and yield/fed of fruits:}

Data in Table (4) reveal that fertilizing parsley plants with all doses of $\mathrm{N}$ fertilizer (except 25\%) + MA significantly promoted the EO $\%$ and yield/fed compared to the control plants in the two experimental seasons. The most effective treatments were mineral $\mathrm{N}$ at $75 \%+\mathrm{MA}$ for $\mathrm{EO} \%$ and $\mathrm{N}$ at $75 \%$ followed by $50 \%$ each plus MA (with no significant differences between themselves) for EO yield/fed in both seasons. These two treatments increased the EO yield of fruits/fed over those of control treatment by 18.88 and $12.48 \%$ in the $1^{\text {st }}$ season and by 18.38 and $11.13 \%$ in the $2^{\text {nd }}$ one, respectively. 
M.K.A. Aly et al.

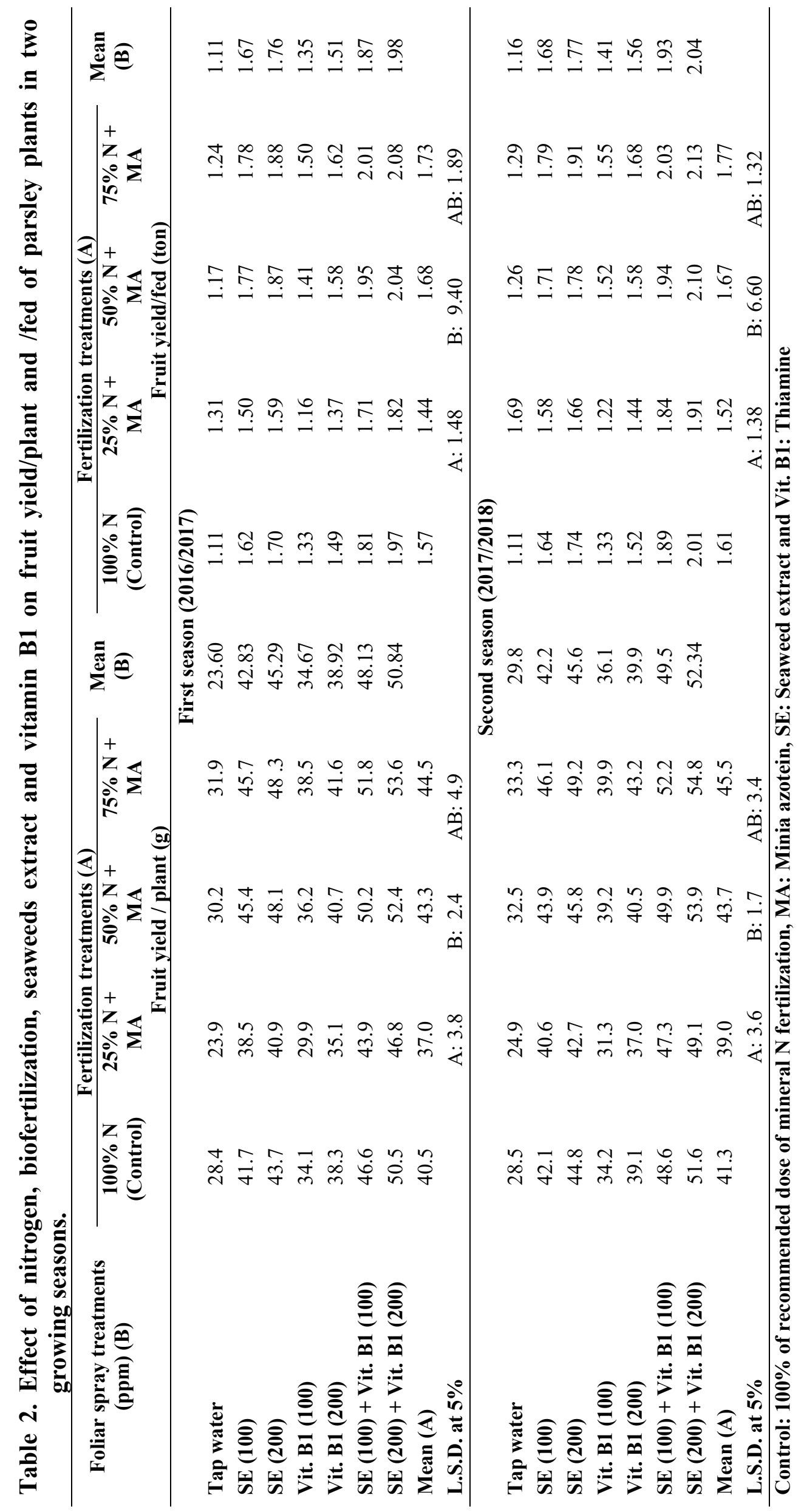


Scientific J. Flowers \& Ornamental Plants, 8(2):235-249 (2021)

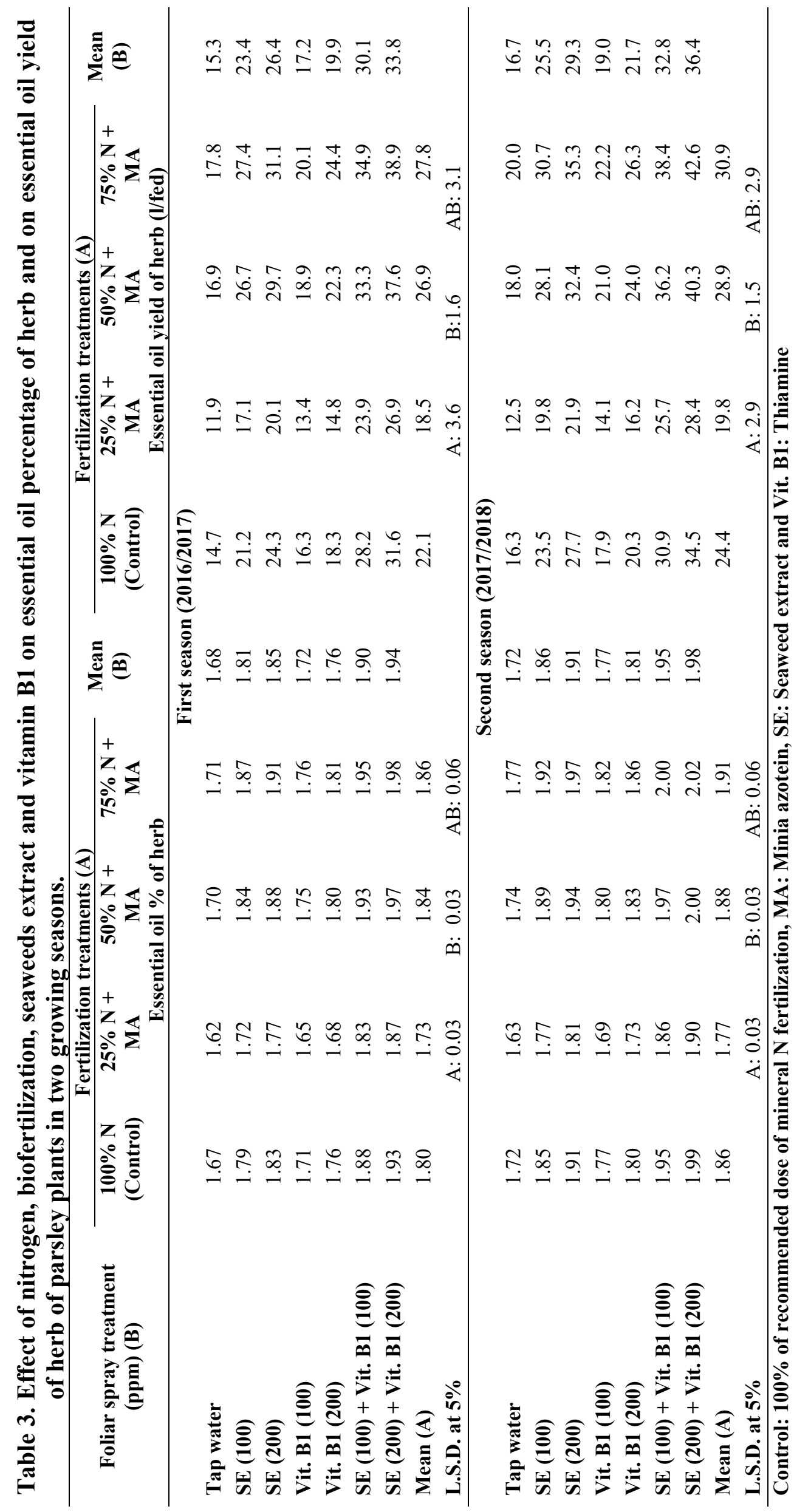


M.K.A. Aly et al.

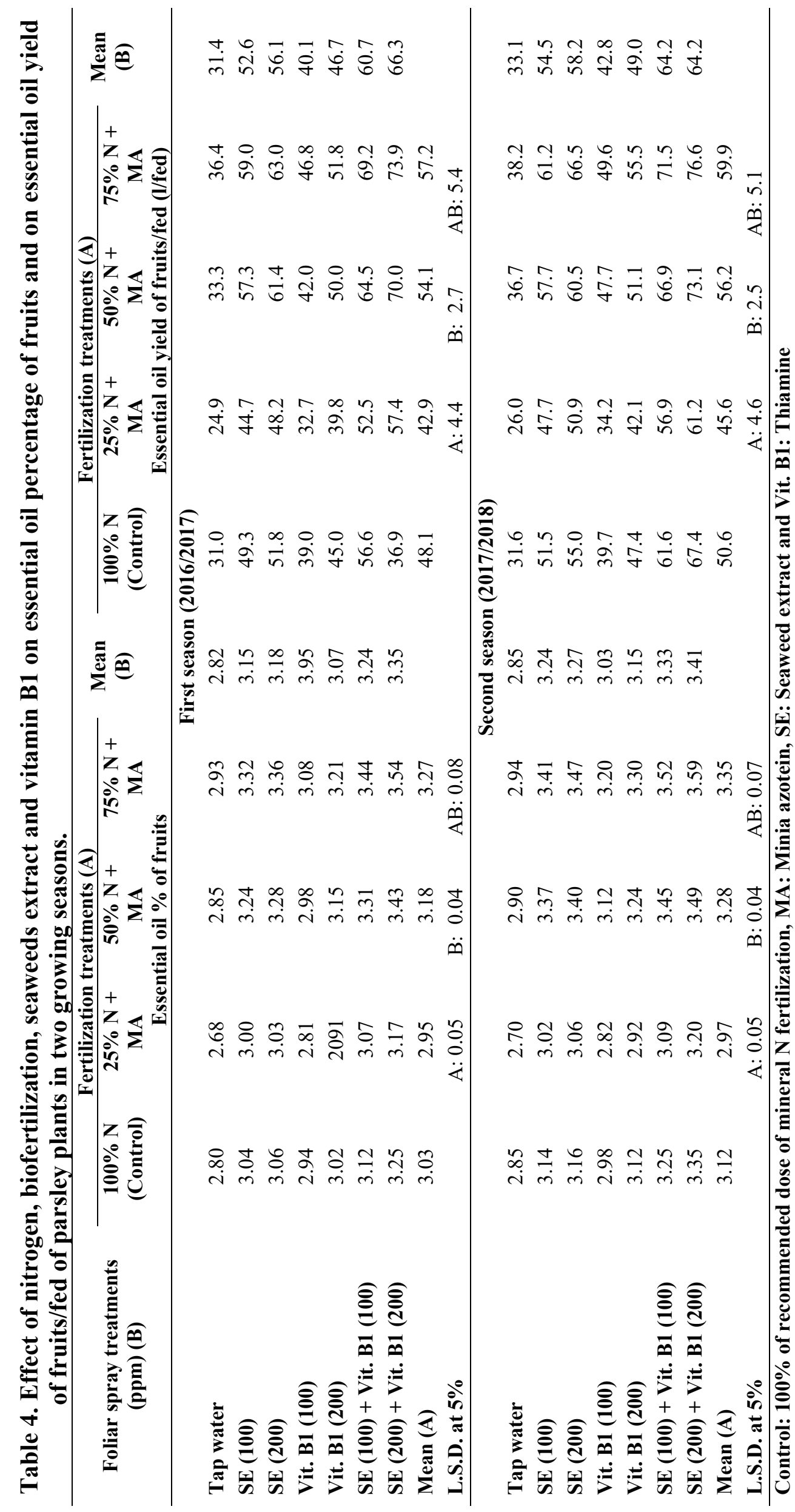


Results in Table (4) show that SE and/or Vit. B1 treatments significantly augmented EO \% and yield/fed compared to untreated plants in the two seasons. The dual treatment was significantly better than the single one, on the other hand, SE was more effective than Vit. B1. Overall, the highest EO \% and yield/fed were obtained from plants treated with SE and Vit. B1 both at 200 ppm, such treatment increased the EO yield of fruits/fed by 111.18 and $109.89 \%$ over those of tap water treatment in both seasons, respectively.

There was a significant interaction between the two investigated factors in both seasons. The highest EO\% of parsley fruit was achieved when the plants treated with $\mathrm{N}$ at $75 \%+\mathrm{MA}$ in combination with $\mathrm{SE}+\mathrm{Vit}$. B1 both at 200 ppm. However, the highest EO yield/fed was produced due to supplying plants with $\mathrm{N}$ fertilizer at $75 \%+\mathrm{MA}$ in combination with SE + Vit. B1 both at 200 or $100 \mathrm{ppm}$ or $\mathrm{N}$ at $50 \%+\mathrm{MA}$ combined with SE + Vit. B1 each at 200 ppm (Table, 4).

\section{Photosynthetic pigments:}

Data presented in Tables (5) and (6) suggested that application of the $\mathrm{N}$ fertilizer at different percentages (except 25\%) + MA significantly increased the content of the three photosynthetic pigments namely, chlorophyll a, b and carotenoids in the fresh leaves of parsley plants compared to the control plants in the two experimental season. Supplying the plants with $\mathrm{N}$ fertilizer at $75 \%+$ MA gave the highest values of the three photosynthetic pigments. Also, the effect of SE and/or Vit. B1 application was significant in both seasons, where the photosynthetic pigments content were significantly augmented with the application of these treatments comparing with tap water treatment (Tables, 5 and 6). The dual treatment of SE + Vit. B1 each at 200 ppm was more effective than the other treatments as it produced the highest content of chlorophyll a, b and carotenoids in both growing seasons.
The interaction between $(\mathrm{N}+$ biofertilization) and (SE and/or Vit. B1) was significant in the two growing seasons. In this concern, the highest values of the three photosynthetic pigments were obtained in plants treated with $\mathrm{N}$ fertilizer at 75 or $50 \%$ + MA in combination with SE + Vit. B1 both at $200 \mathrm{ppm}$ in both experimental seasons.

\section{Nitrogen percentage:}

It is evident from the data exhibited in Table (6) that $\mathrm{N} \%$ in the dry leaves was enhanced in the parsley plants treated with $\mathrm{N}$ fertilizer at all percentages (except 25\%) + MA as compared to the control plants in the two growing seasons. The highest $\mathrm{N} \%$ was obtained due to applying mineral $\mathrm{N}$ fertilizer at $75 \%+$ MA in both seasons (Table, 6 ).

Also, all treatments of SE and/or Vit. B1 caused a significant increase in the $\mathrm{N}$ percentage in the dry leaves of parsley plants comparing with tap water treatment in both growing seasons. Treating plants with $\mathrm{SE}+$ Vit. B1 both at $200 \mathrm{ppm}$ increased the content of $\mathrm{N}$ to the highest percentage in both seasons.

There was a significant interaction between ( $\mathrm{N}$ and biofertilizetion) and (SE and/or Vit. B1) treatments in both seasons. The highest accumulation of $\mathrm{N} \%$ was obtained due to treating parsley plants with $\mathrm{N}$ fertilizer at $75 \%$ or $50 \%$ each one plus MA combined with SE + Vit.B1 both at 200 ppm in the two growing seasons.

\section{DISCUSSION}

Parsley plants treated with the recommended dose of $\mathrm{N}$ had significantly higher herb dry as well as fruit yield (101.8 and $28.4 \mathrm{~g} /$ plant respectively) in the $1^{\text {st }}$ season compared with those treated with $25 \%$ of the recommended dose of $\mathrm{N}$ even with MA (89.7 and 23.95 g/plant respectively) and similar results were estimated in the $2^{\text {nd }}$ season. The vital role of $\mathrm{N}$ in plant growth is well documented $\mathrm{N}$ is an essential component in amino acids formation, cell division, photosynthetic, vitamins and carbohydrates production 
M.K.A. Aly et al.

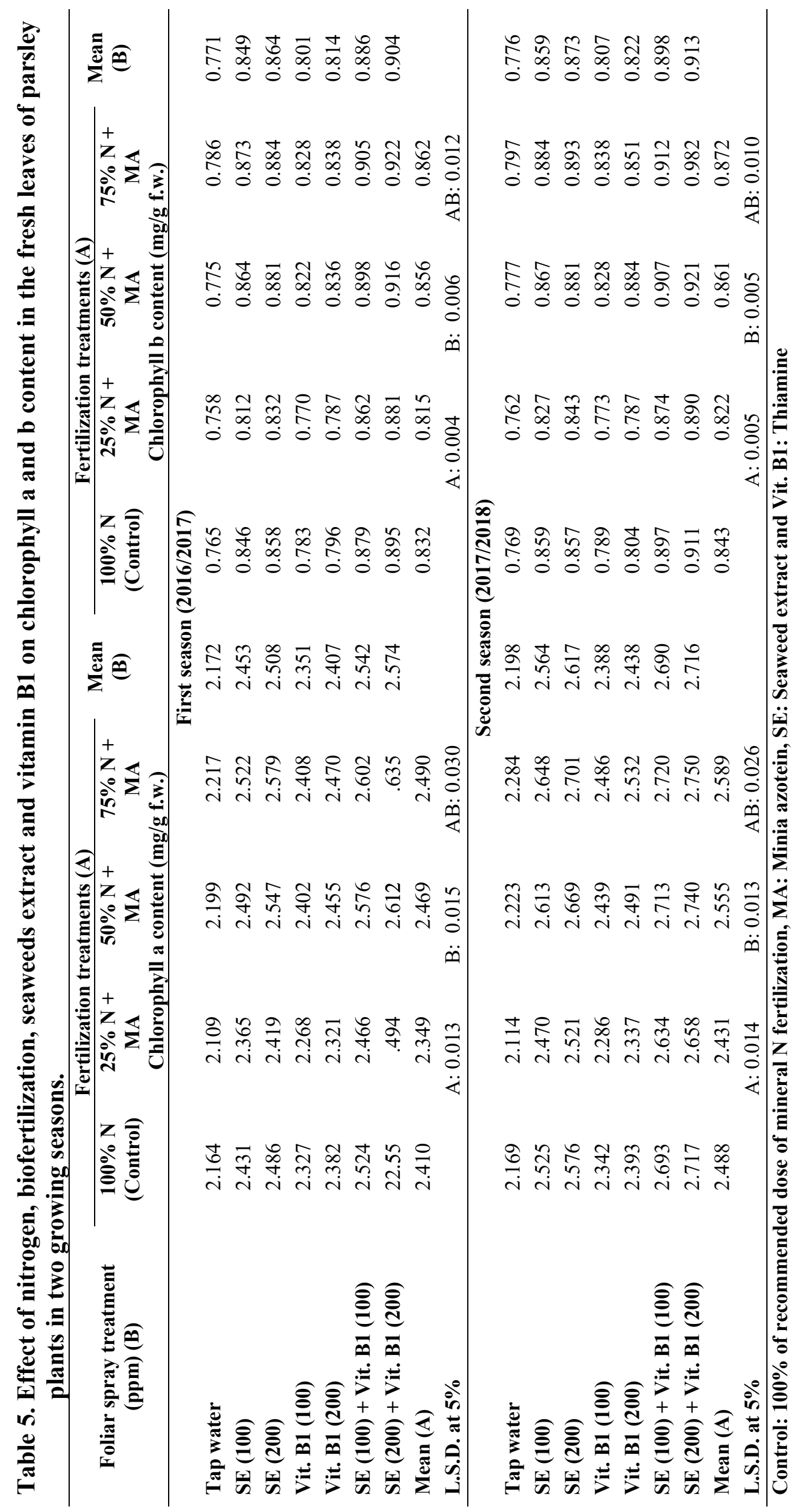


Scientific J. Flowers \& Ornamental Plants, 8(2):235-249 (2021)

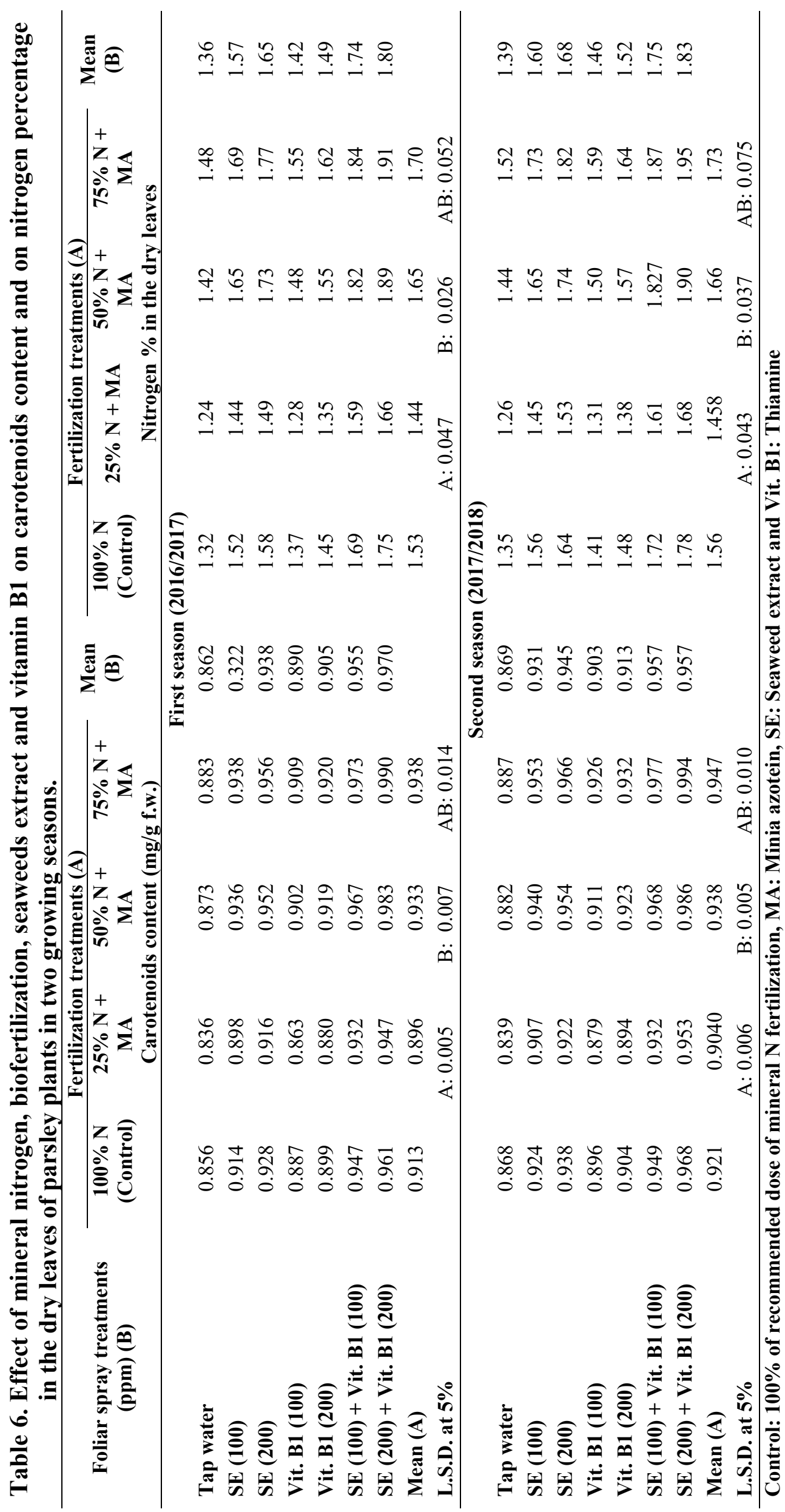


(Mengel et al., 2001). It is the most vital nutrient element for plant growth, development and application of adequate amount of $\mathrm{N}$ is compulsory for successful crop production particularly non-legume plants (Baset, 2015).

Results showed that MA (N-fixing bacteria) could partially supply the parsley plant by its $\mathrm{N}$ requirements. For example, plants inoculated with MA and received only $75 \%$ of the recommended dose of $\mathrm{N}$ had significantly higher herb dry and fruit weights than plants fertilized with the full dose of the recommended N. Moreover, the obtained results showed that the EO percentage in the herb as well as the fruits were increased due to MA inoculation in addition to $75 \%$ of $\mathrm{N}$ to 1.86 and $3.27 \%$ respectively in the $1^{\text {st }}$ season whereas the control plants had 1.67 and $2.80 \%$ respectively. For most estimated traits plants treated with $50 \% \quad \mathrm{~N}$ and $\mathrm{MA}$ had significantly higher or at least similar values like those treated with $100 \%$ of $\mathrm{N}$ in both seasons.

In this regard, Bhattacharjee and Day (2014) stated that biofertilizers colonize the rhizosphere and increase the amount or availability of primary nutrients and/or growth stimulus to the plant. The benefits of biofertilisers in the improvement of plant production and enhancing its quality are widely discussed. Biofertilizers play a significant role in improving soil fertility and structure due to adding organic matter to it (Son et al., 2007). It has been reported that growth, yield and quality parameters of certain plants significantly improved when inoculated with $\mathrm{N}$ fixers (Youssef and Eissa, 2014). Moreover, it produced some photohormones such as indole acetic acid, gibberellins and cytokinins, as well as, antibacterial substances which is vital (Hauwka, 2000). Our results were similar to those reported by Abdallah et al. (2012) and Shehata (2019) on parsley; Abdou et al. (2020) on fennel and El-Sayed et al. (2020) on dill.
The recent study showed that SE as well as Vit. B1 significantly increased almost all assessed traits compared with that of tap water treated plant on both seasons. Moreover, the higher dose of any of them had better effect. These results are similar to those obtained by Ramya et al. (2011) on guar; Aqeel et al. (2014) on Nigella sativa; Hassan (2015) on Anethum graveolens; Mahmoud (2016) on Calendula officinalis and Veeranan et al. (2018) on Ocimum sanctum. Seaweed extract containing macronutrients, trace elements, organic substances like amino acids and plant growth regulators such as auxins, cytokinins and gibberllins, vitamins and fatty acids (Chapman and Chapman, 1980). They enhanced the crop yield by improving root growth and structures, which finally improved plant development included leaf development, fruit set and better ability to tolerate biotic and biotic stress (Calvo et al., 2014 and Drobek et al., 2019). Thiamin (Vit. B1) function as growth regulator or hormone precursor (Samiullah, 1988) and plays essential role as a cofactor for important metabolic activities (Colinas et al., 2015). It plays an important role through increasing carbon assimilation and transfers it into storage sinks (Fitzpatrick and Chapman, 2020). Vit. B1 has been used as a biostimulants by (Hendawy and Ezz El-Din, 2012 on fennel; Botros, 2013 on caraway; Abdelkader et al., 2018 on black cumin and Abdou et al., 2019 on cumin).

Results showed that $\mathrm{N}+\mathrm{MA}, \mathrm{SE}$ and Vit. B1 had significant effects on growth, yield and EO of parsley plants. All N fertilizer + MA treatments except $\mathrm{N}$ at $25 \%$ significantly improved almost all investigated traits over those of plants treated with the recommended dose of $\mathrm{N}$. The herb dry and fruit weights were significantly increased following the application of $\mathrm{N}$ fertilizer at $75 \%$ or at $50 \%$ each one plus MA combined with SE + Vit. B1 both at 200 ppm in the two growing seasons. This combined treatment increased the herb dry weight to $214.5 \mathrm{~g} /$ plant whereas, control the plants which treated with tap water had 
$101.8 \mathrm{~g} /$ plant $\left(1^{\text {st }}\right.$ season $) . \quad$ Moreover, the above-mentioned treatment increased the fruit yield of parsley plants from $28.4 \mathrm{~g} /$ plant to $53.60 \mathrm{~g} / \mathrm{plant}$. Therefore, supplying parsley plants with the mineral $\mathrm{N}$ fertilizer at $50 \%$ as ammonium sulphate plus MA combined with seaweeds extract + Vit. B1 both at $200 \mathrm{ppm}$ is suggested to maximize the herb, fruits and EO productivity and reducing mineral $\mathrm{N}$ fertilizer by $50 \%$.

\section{REFERENCES}

Abdallah, A.R.; Safwat, M.S.A.; Moharram, T. and Ahmed, T.M. (2012). Biofertilizers: a potential approach for sustainable. AGRIS Since, 34:769-779.

Abdelkader, M.A.I.; Fahmy, A.A.; Elakkad, H. and Hussein, S.S.E. (2018). Response of Nigella sativa growth, productivity and chemical constituents to foliar application by some antioxidant compounds. Bioscience Research, 15:3214-3230.

Abdou, M.A.H.; El-Sayed, A.A.; Taha R.A.; Ahmed; S.K. and El-Nady, M.K. (2019). Response of cumin plant to some organic, biofertilization and antioxidant treatments I. Vegetative growth and fruits yield. Proc. the $5^{\text {th }}$ Conf. of SSFOP "Maximizing Utilization of Ornamental Plants in Urban Areas Landscaping", Cairo, Egypt, Scientific J. Flowers \& Ornamental Plants, 6(1):81-88.

Abdou, M.A.H.; Helmy, T.A.; Salam, M.S.; Abdel-Rahim, A.F.A. and Hassan, A.A. (2020). Effect of organic and biofertilization treatments on fennel plant under drip irrigation system in Bahria Oases, II- Oil productivity and some chemical compounds. Scientific Journal of Agricultural Sciences, 2:72-79.

Aqeel, N.A.; Almehemdi, A.F. and Al Ajeelee, R.K. (2014). Impact of bat guano Otonycteris hemprichii Camd and seaweed extract on some growth and yield traits of Baraka seed Nigella Sativa L. Journal of Biology, Agriculture and Healthcare, 4: 57-65.
Baset, M.A.M. (2015). Plant Science Research and Practices, Nutrition of Crop Plants. NOVA Publisher, UK, 197 p.

Behtash, N.; Kargarzadeh, F. and Shafaroudi H. (2008). Analgesic effects of seed extract from Petroselinum crispum in animal models. Toxicology Letters, (Suppl 5), S127-S128. dx.doi.org/10.1016/j.toxlet.2008.06.743

Bhattacharjee, R. and Utpal, D. (2014). Biofertilization, a way towards organic agriculture: A review. African of Microbiology Research, 8:2332-2343.

Blumenthal, M.; Goldberg, A. and Brinckman, J. (2000). Herbal Medicine: Expanded Commission E Monographs. Integrative Medicine Communications, Newton, UK, pp. 78-83.

Botros, W.S.E. (2013). Physiological Studies on Caraway Plants. M.Sc, Thesis, Fac. Agric, Minia Univ., Egypt, 109 p.

British Pharmacopoeia

(1963). Determination of volatile oil drugs. The Pharmdceutical Press, London, UK., $1210 \mathrm{p}$.

Calvo, P.; Nelson, L. and Kloepper, J.W. (2014). Agricultural uses of plant biostimulants. Plant Soil, 383:3-41.

Chapman,V.J. and Chapman, D.J. (1980). Seaweeds and Their Uses ( $3^{\text {rd }}$ Edtion). Chapman and Hall, London, UK, 334 p.

Chatterjee, R.; Roy, A. and Thirumdasu, R.K. (2017). Microbial inoculants in organic vegetable production: Current perspective. In: Zaidi, A. and Khan, M.S. (eds.), Microbial Strategies for Vegetable Production, Springer, pp. 1-21.

Colinas, M. and Fitzpatrick, T.B. (2015). Natures balancing act: Examining biosynthesisde novo, recycling and processing damaged vitamin $\mathrm{B}$ metabolites. Current Opinion in Plant Biology, 25: 98-106.

Diaz-Maroto, M.C.; Perez-Coello, M.S. and Cabezudo, M.D. (2002). Effect of different drying methods on the volatile 
components of parsley (Petrosolinum crispum L.), Eur. Food Res. Technol., 215: 227-234.

Drobek, M.; Frac, M. and Cybulska, J. (2019). Plant biostimulants: Importance of the quality and yield of horticulture crops and the improvement of plant tolerance to abiotic stress - A Review. Agronomy, 9(6):1-18. https://doi.org/10.3390/agronomy906033 5

Elsayed, S.I.M; Glala, A.A.; Abdalla, A. M.; and El-Sayed, A.G. and Darwish, M.A. (2020). Effect of biofertilizer and organic fertilization on growth, nutrient content and yield of dill (Anethum graveolens). Bulletin of the National Research center, 44:1-10. https://doi.org/10.1186/s42269020-00375-z

Fadl, M.S. and Seri El-Deen, S.A. (1978). Effect of N-benzyladenine on photosynthetic pigments and total soluble sugars of olive seedlings grown under saline conditions. Res. Bull., Fac. Agric., Ain Shams Univ., Egypt, 873 p.

Fitzpatrick, T.B. and Chapman, L.M. (2020). The importance of thiamine (vitamin B1) in plant health: From crop yield to biofortification. J. Biol. Chem., 15: 295376.

Hassan, E.A. (2015). Influence of mixed minerals ores and seaweed liquid extract on growth, yield and chemical constituents of dill (Anethum graveolens, L.) plants. Middle East Journal of Applied Sciences, 5: 751-758.

Hawuka, F.I.A. (2000). Effect of using single and composite inoculation with Azospirillum, brasilense, Bacillus megatherium var. phosphalicum and Glomus macrocarpus for improving growth of Zea mays. J. Agric. Sci. Mansoura Univ., 25: 239-252.

Hendawy, S.F. and Ezz El-Din., A.A. (2010). Growth and yield of Foeniculum vulgare var. Azoricum as influenced by some vitamins and amino acids. Ozean Journal of Applied Sciences, 3: 113-123.

Khan, W.; Rayirath, U.P.; Subramanian, S.; Jithesh, M.N.; Rayorath, P.; Flodges, D.M.;Critchley, A.T.; Craigie, J.S.; Norrie, J. and Prithiviraj, B. (2009). Seaweed extracts as bio stimulants of plant growth and development. Plant Growth Regul., 28: 386-399.

Mead, R.; Currow, R.N. and Harted, A.M. (1993). Statistical Methods in Agricultural and Experimented Biology and $2^{\text {nd }}$ Edition. Chapman and Hall, London, UK, $472 \mathrm{p}$.

Mengel, K.; Kirkby, E.A.; Kosegarten, H. and Appel, T. (2001). Principles of Plant Nutrition. Dordrecht Kluwer Academic, The Netherland. 849 p.

Moazedi, A.A.; Mirzaie, D.N.; Seyyednejad, S.M.; Zadkarami, M.R. and Amirzargar, A. (2007). Spasmolytic effect of Petroselinum crispum (Parsley) on rat's ileum at different calcium chloride concentrations. Pakistan J. of Biolo. Sci., 10: 4036-4042.

Mohamed, E.A.S. (2016). Enhancement the characters of calendula plants grown under saline and non-saline conditions by using growth stimulants Ph.D. Thesis, Fac., Agric. Cairo Univ., Egypt, 123 p.

MSTATC (1986). A microcomputer program for design, management and analysis of agronomic research experiments (version 4), Michigan State Univ., USA.

Ramya, S.S.; Nagarajm, S. and Vijayanand, N. (2011). Influence of seaweed liquid extract on growth, biochemical and yield characteristics of Gyamopsis tetragonoloba, H. Taub. J. of Phytology, $3: 37-41$.

Samiullah, S.A; Ansari, M.M. and Afridi, RK. (1988). B-vitamin in relation to crop productivity. Indi Rev. Life Sci., 8: 5174. 
Shehata, M.N. (2019). Parsley productivity and essential oil content as affected by chemical, bio-fertilization and humic acid. Proc. $9^{\text {th }}$ International Conference for Sustainable Agricultural Development, 4-6 March 2019, Fayoum J. Agric. Res.\& Dev., 33:280-296.

Simon, J. (1990). Essential oil and culinary herbs. In: Janick, J.; Simon, J.E. (eds.), Advances in Now Crops, Timber Press, Portland, UK, pp. 472-483.

Son T.N.; Thu, V.V.; Dung, V.C. and Hiraoka, H. (2007). Effect of organic and bio-fertilizers on soybean and rice cropping system. Japan International Research Center for Agric. Sci., Tsukuba, Ibaraki, Japan.

Subki, A.; Abidin, A.A.Z. and Yusof Z.N.B. (2018). The role of thiamine in plants and current perspectives in crop improvement. In: LeBlanc, J.G. and De Giori, G.S. (eds.) B Group Vitamins, Current Uses and Perspectives, IntechOpen, pp. 33-44. https://doi.org/10.5772/intechopen.79350
Torre, A.; Battaglia V. and Caradonia, F. (2013). Legal aspects of the use of plant strengtheners (biostimulants) in Europe. Bulgarian Journal of Agricultural Science, 19: 1183-1189.

Veeranan, U.; Selvam, S.; Ponnerulan, B.; Saminathan, E.; Subramanian, S.; Narayanan, V. and Durairaj, K. (2018). Biofertilizing potential of seaweed liquid extracts of marine macro algae on growth and biochemical parameters of Ocimum sanctum. Journal of Pharmacognosy and Phytochemistry, 7: 3528-3532.

Wilde, S.A.; Corey, R.B.; Lyer, J.G. and Voigt, G.K. (1985). Soil and Plant Analysis for Free Culture. Oxford, IBJH, New Delhi, India. pp. 70-94.

Youssef, M.M.A and Eissa, M.F.M (2014). Biofertilizers and their role in management of plant parasitie nematodes- A review. J. Biotech Pharmaceut. Res., 5:1-6.

\section{تأثير التسميد النيتروجينى والحيوي ومستخلص الأعشاب البحرية والثيامين على النمو والمحصول

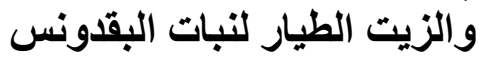

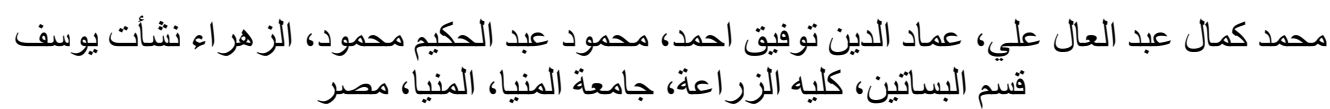

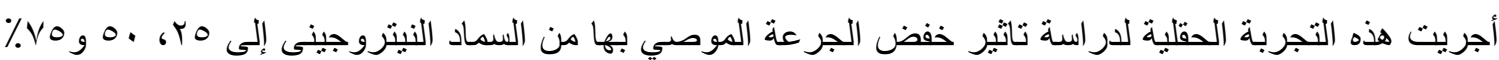
على نباتات البقدونس باستخدام بعض المنشطات الحيوية كبديل، فاستعملت البكتريا المثبتة للنيتروجين (المستحضر

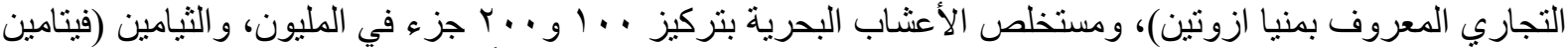

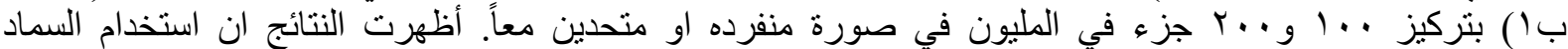

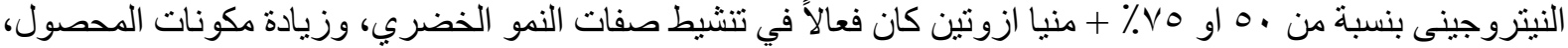

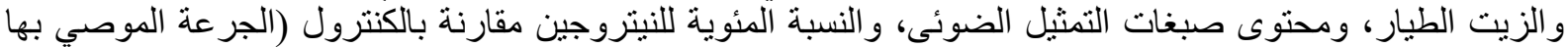

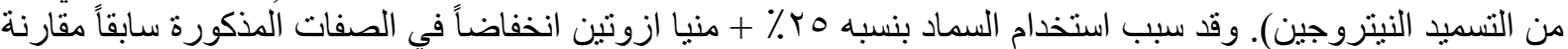

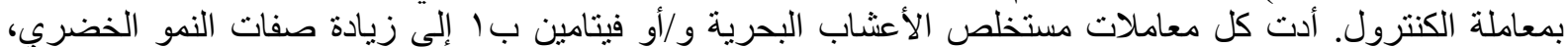

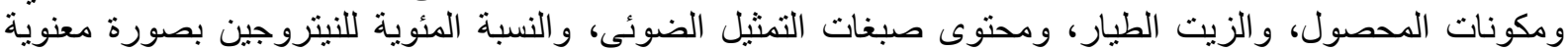

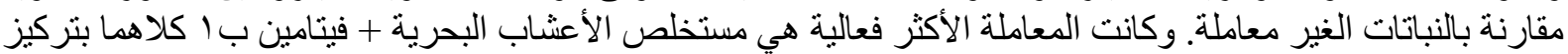

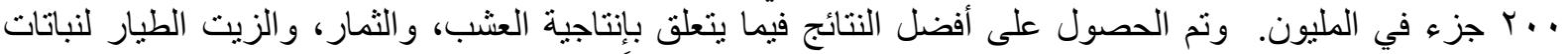

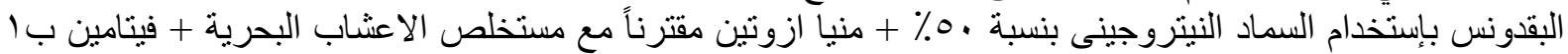

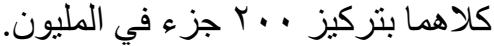

